\title{
Efektivitas Kinerja Dosen Berdasarkan Persepsi Mahasiswa Program Studi Pendidikan Biologi Universitas Cenderawasih
}

\author{
Maik Akobiarek*1, Ruth Megawati ${ }^{2}$, Jirana $^{3}$ \\ ${ }^{1,2}$ Universitas Cenderawasih \\ ${ }^{3}$ Universitas Sulawesi Barat \\ e-mail: *113akobiarekmaik@gmail.com, ${ }^{2}$ ruthmegawati@yahoo.com, ${ }^{3}$ jirana@ unsulbar.ac.id
}

\begin{abstract}
Abstrak
Penelitian ini merupakan penelitian survey yang dilakukan untuk mendapatkan gambaran kinerja dosen program studi pendidikan biologi semester ganjil tahun akademik 2015/2016. Instrumen utama dalam penelitian ini adalah kuisioner yang telah diuji valid dengan menggunakan rumus pearson product moment serta diuji reliabilitasnya dengan menggunakan rumus alpha cronbach, dan pedoman wawancara sebagai pelengkap. Data yang terkumpul dianalisis secara deskriptif kuantitatif yaitu dengan mendeskripsikan dan memaknai data dari masing-masing aspek yang diteliti, yang selanjutnya akan disusun dalam tabel klasifikasi/kategori kinerja dosen. Berdasarkan hasil analisis data yang dilakukan secara umum rerata penilaian mahasiswa berada pada rentang nilai 3.4 - 4,7 (rentang nilai tertinggi) walaupun ada tiga penilaian yang berada pada rentang nilai 2,0 - 2,9. Hal ini menunjukkan bahwa sebagian besar dosen mendapat penilaian baik dari mahasiswa. 19 mata kuliah yang berada pada kategori baik berdasarkan hasil analisis ini didukung oleh penyataan mahasiswa langsung dan pengalaman yang dirasakan selama perkuliahan yang diberikan oleh dosen yang bersangkutan. Keefektifitasan pembelajaran dirasakan oleh mahasiswa dapat dijelaskan berdasarkan indikator dari hasil yang diperoleh. Temuan penelitian menunjukkan bahwa banyak factor yang mempengaruhi kinerja dosen salah satunya adalah kompetensi professional (kompetensi pedagogic). Oleh karena itu, untuk mengoptimalkan kinerja dosen harus diupayakan pula bagaimana meningkatkan kompetensi professional sehingga dosen dapat menjalankan tugasnya lebih baik lagi.
\end{abstract}

Kata kunci efektifitas, kinerja, dosen

\section{PENDAHULUAN}

Pendidikan merupakan wadah untuk menghasilkan sumber daya manusia melalui jalur pendidikan formal dari tingkat dasar, menengah sampai dengan perguruan tinggi ataupun melalui jalur nonformal. Untuk menciptakan sumber daya manusia yang berkualitas dan memiliki kemampuan dalam segala aspek kehidupan dapat dilakukan melalui pengembangan mutu pendidikan di setiap jenjang pendidikan mulai dari tingkat dasar, menengah dan perguruan tinggi. Pelaksanaan kegiatan proses belajar mengajar yang berjalan dengan baik, lancar dan sesuai dengan kaidah-kaidah pembelajaran diyakini mampu menghasilkan hasil belajar yang optimal.

Program studi pendidikan biologi adalah salah satu program studi di Jurusan Pendidikan MIPA FKIP Universitas Cenderawasih yang menghasilkan guru dan praktisi biologi. Salah satu misi dari program studi pendidikan biologi adalah menghasilkan tenaga kependidikan (guru) 
dan praktisi biologi yang memiliki kompetensi keguruan dan keilmuan yang tinggi. Untuk menghasilkan guru dan praktisi pendidikan biologi yang berkompeten tentunya dipengaruhi oleh banyak faktor baik yang bersifat internal maupun eksternal. Faktor internal yaitu faktor yang berasal dari dalam diri mahasiswa sebagai subjek belajar antara lain minat, motivasi, bakat dan intelegensi, sedangkan faktor eksternal berupa sarana prasarana perkuliahan, kurikulum, dosen, lingkungan kampus, lingkungan keluarga, lingkungan masyarakat dan lain-lain.

Kinerja dosen dalam mengajar merupakan salah satu faktor yang cukup penting dalam menghasilkan output/ lulusan yang berkompeten. Sebagaimana diatur dalam Undang-Undang Guru dan Dosen No.14 Tahun 2005, ditegaskan bahwa dosen harus memiliki kompetensi pedagogik, kompetensi profesional, kompetensi kepribadian dan kompetensi sosial agar dapat melaksanakan tugas dan tanggung jawabnya sesuai dengan yang diatur oleh Undang-Undang.

Dosen dilingkungan Program Studi Pendidikan Biologi mempunyai tugas dan tanggung jawab untuk menghasilkan guru dan praktisi pendidikan biologi yang memiliki kompetensi yang memadai untuk diterjunkan ke sekolah-sekolah sebagai stakeholders.

Berdasarkan hasil observasi awal dan wawancara dengan mahasiswa sebagai subjek utama yang menerima dampak langsung dalam proses belajar mengajar di program studi, maka perlu dilakukan penelitian ini sebagai bentuk evaluasi yang komprehensif untuk melihat sejauh mana efektivitas proses belajar mengajar dan kinerja dosen program studi pendidikan biologi pada semester ganjil tahun akademik 2015/2016.

Melalui studi evaluatif ini akan diperoleh datasejauh mana kinerja dan capaian dosen dalam proses belajar mengajar di Program Studi Pendidikan Biologi yang selanjutnya data tersebut akan digunakan sebagai feedback bagi pengembangan dan peningkatan kualitas proses belajar mengajar di Program Studi Pendidikan Biologi, Universitas Cenderawasih.

\section{METODE PENELITIAN}

Penelitian ini merupakan penelitian survey yang dilakukan untuk mendapatkan gambaran kinerja dosen program studi pendidikan biologi semester ganjil tahun akademik 2015/2016. Populasi dalam penelitian ini adalah seluruh mahasiswa program studi pendidikan biologi yang terdaftar aktif pada semester ganjil tahun akademik 2015/2016. Sampel dipilih secara acak (random sampling) 5 sampai 10 orang mahasiswa per mata kuliah. Instrumen utama dalam penelitian ini adalah kuisioner yang telah diuji valid dengan menggunakan rumus pearson product moment serta diuji reliabilitasnya dengan menggunakan rumus alpha cronbach, dan pedoman wawancara sebagai pelengkap. Kuisioner untuk mengukur kinerja dosen menggunakan skala likert, yang terlebih dahulu telah diuji valid dan reliable. Data yang terkumpul dianalisis secara deskriptif kuantitatif yaitu dengan mendeskripsikan dan memaknai data dari masing-masing aspek yang diteliti.Penentuan klasifikasi kinerja dosen dilakukan dengan langkah-langkah dalam analisis data sebagai berikut: (1). Penskoran jawaban dari responden; (2). Menjumlahkan skor total dari masing-masing aspek; (3). Mengelompokkan skor yang didapat; (4). Melihat persentase tingkat kecenderungan dengan kategori yang ada sehingga diperoleh informasi mengenai hasil penelitian; (5). Menyusun tabel klasifikasi kinerja dosen

Tabel 1 Klasifikasi Kinerja Dosen

\begin{tabular}{|c|c|c|}
\hline Jumlah Skor & Rerata Skor & Klasifikasi Kinerja \\
\hline $101,2-120$ & $4,2-5,00$ & Sangat Baik \\
\hline
\end{tabular}




\begin{tabular}{|c|c|c|}
\hline $81,9-101,1$ & $3,41-4,2$ & Baik \\
\hline $62,6-81,8$ & $2,60-3,41$ & Kurang Baik \\
\hline $43,3-62,5$ & $1,80-2,60$ & Tidak Baik \\
\hline $24-43,2$ & $1,00-1,80$ & Sangat Tidak Baik \\
\hline
\end{tabular}

(Widoyoko, 2012).

\section{HASIL DAN PEMBAHASAN}

Pengumpulan data pada penelitian ini dengan menggunakan kuesioner. Data yang diperoleh berdasarkan hasil pengisian kuesioner yang diberikan kepada mahasiswa yang mengikuti perkuliahan dosen tersebut, dengan jumlah dosen sebanyak 21 orang yang mengajar pada Program Studi Pendidikan Biologi, Universitas Cenderawasih.

Berdasarkan tabel 1 di atas, maka dari hasil analisis data Kinerja Dosen pada Program Studi Pendidikan Biologi,Universitas Cenderawasih dapat di kategorikan sebagi berikut.

Tabel 2 Pengkategorian Kinerja Dosen Program Studi Pendidikan Biologi, Uncen.

\begin{tabular}{|l|l|l|l|}
\hline No & $\begin{array}{l}\text { Mata } \\
\text { kuliah }\end{array}$ & $\begin{array}{l}\text { Dosen } \\
\text { Pengampu }\end{array}$ & Klasifikasi \\
\hline 1 & $\begin{array}{l}\text { Biologi } \\
\text { Sel }\end{array}$ & RR & BAIK \\
\hline 2 & Evolusi & AR & $\begin{array}{l}\text { SANGAT } \\
\text { BAIK }\end{array}$ \\
\hline 3 & BTR & DL & $\begin{array}{l}\text { KURANG } \\
\text { BAIK }\end{array}$ \\
\hline 4 & Biometrika & Tt & BAIK \\
\hline 5 & Konservasi & AA & $\begin{array}{l}\text { SANGAT } \\
\text { BAIK }\end{array}$ \\
\hline 6 & $\begin{array}{l}\text { Penelitian } \\
\text { Pendidikan } \\
\text { Biologi }\end{array}$ & Tt & BAIK \\
\hline 7 & Biokimia & VP & BAIK \\
\hline 8 & Etnobotani & VE & BAIK \\
\hline 9 & $\begin{array}{l}\text { Fisika } \\
\text { Dasar 1 }\end{array}$ & JP & BAIK \\
\hline 10 & PKI & ER & $\begin{array}{l}\text { SANGAT } \\
\text { BAIK }\end{array}$ \\
\hline 11 & Seminar & LA & BAIK \\
\hline 12 & $\begin{array}{l}\text { Biologi } \\
\text { Umum }\end{array}$ & JK & BAIK \\
\hline 13 & $\begin{array}{l}\text { Pengantar } \\
\text { Pendidikan }\end{array}$ & TG & BAIK \\
\hline 14 & $\begin{array}{l}\text { Agama } \\
\text { Kristen } \\
\text { Protestan }\end{array}$ & ZT & BAIK \\
\hline 15 & $\begin{array}{l}\text { Agama } \\
\text { Islam }\end{array}$ & AR & BAIK \\
\hline 16 & Pancasila & HU & BAIK \\
\hline & & & \\
\hline
\end{tabular}




\begin{tabular}{|c|l|l|l|}
\hline 17 & Kalkulus 1 & GS & BAIK \\
\hline 18 & $\begin{array}{l}\text { Zoologi } \\
\text { Invertebrat } \\
\text { a }\end{array}$ & RR & $\begin{array}{l}\text { KURANG } \\
\text { BAIK }\end{array}$ \\
\hline 19 & Genetika & AU & $\begin{array}{l}\text { SANGAT } \\
\text { BAIK }\end{array}$ \\
\hline 20 & $\begin{array}{l}\text { Teknik } \\
\text { Lab }\end{array}$ & AU & $\begin{array}{l}\text { SANGAT } \\
\text { BAIK }\end{array}$ \\
\hline 21 & $\begin{array}{l}\text { Morfologi } \\
\text { Tumbuhan }\end{array}$ & KK & BAIK \\
\hline 22 & $\begin{array}{l}\text { Morfologi } \\
\text { Tumbuhan }\end{array}$ & AA & $\begin{array}{l}\text { SANGAT } \\
\text { BAIK }\end{array}$ \\
\hline 23 & $\begin{array}{l}\text { Fisiologi } \\
\text { Tumbuhan }\end{array}$ & Tt & BAIK \\
\hline 24 & $\begin{array}{l}\text { Fisiologi } \\
\text { Hewan }\end{array}$ & RR & $\begin{array}{l}\text { TIDAK } \\
\text { BAIK }\end{array}$ \\
\hline 25 & $\begin{array}{l}\text { Perkemban } \\
\text { gan } \\
\text { Tumbuhan }\end{array}$ & MA & $\begin{array}{l}\text { SANGAT } \\
\text { BAIK }\end{array}$ \\
\hline 26 & $\begin{array}{l}\text { Bahasa } \\
\text { Inggris }\end{array}$ & WI & BAIK \\
\hline 27 & $\begin{array}{l}\text { Perkemban } \\
\text { gan } \\
\text { Peserta } \\
\text { didik }\end{array}$ & YI & BAIK \\
\hline 28 & ISBD & MR & BAIK \\
\hline 29 & $\begin{array}{l}\text { PHB } \\
\text { Tt }\end{array}$ \\
\hline
\end{tabular}

Penjabaran kinerja dosen dapat dilihat pada gambar dibawah ini.

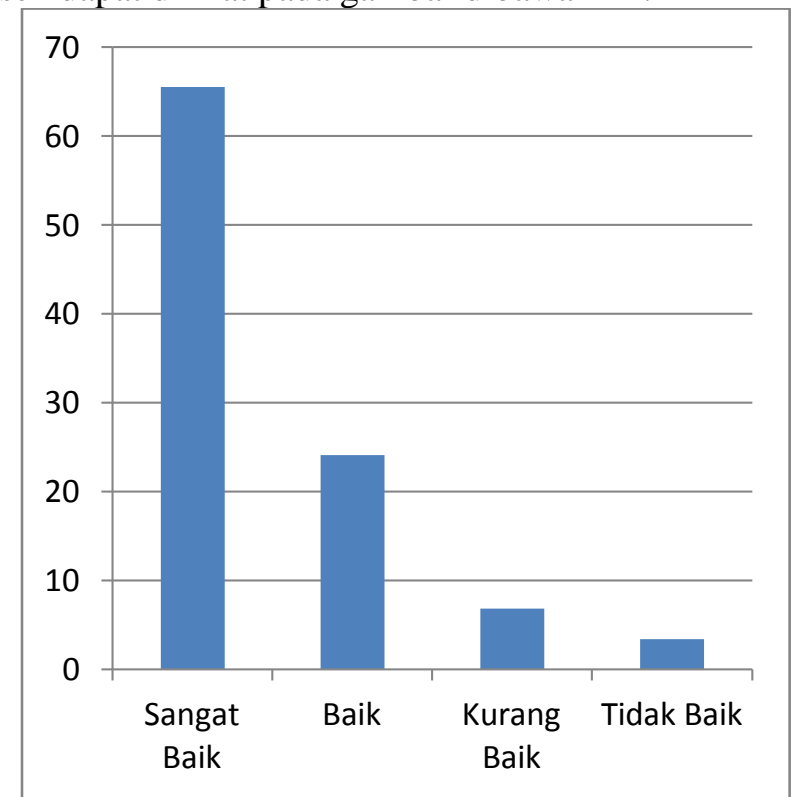

Gambar 1 Kinerja Dosen Program Studi Pendidikan Biologi 
Berdasarkan tabel 2 di atas, diketahui sebagian besar kinerja dosen berada pada kategori Baik (19 Mata Kuliah), selanjutnya diikuti oleh kategori sangat Baik (7 mata kuliah) dan kategori kurang baik (2 mata kuliah) dan terakhir satu (1) mata kuliah yang berada pada kategori tidak baik.

Sebanyak 29 mata kuliah pada semester ganjil tahun ajaran 2015/2016 ada beberapa dosen yang menggampuh satu atau lebih mata kuliah sehingga dalam hal ini, dosen bersangkutan mendapatkan dua kali penilaian dari mahasiswa yang dipilih sebagai sampel, mahasiswa tetap memberikan penilaian kepada dosen yang bersangkutan berdasarkan mata kuliah yang diampuhnya.

Berdasarkan hasil analisis data yang dilakukan secara umum rerata penilaian mahasiswa berada pada rentang nilai $3.4-4,7$ (rentang nilai tertinggi) walaupun ada tiga (3) penilaian yang berada pada rentang nilai 2,0 - 2,9. Hal ini menunjukkan bahwa sebagian besar dosen mendapat penilaian baik dari mahasiswa. 19 mata kuliah yang berada pada kategori baik berdasarkan hasil analisis ini didukung oleh penyataan mahasiswa langsung dan pengalaman yang dirasakan selama perkuliahan yang diberikan oleh dosen yang bersangkutan. Keefektifitasan pembelajaran dirasakan oleh mahasiswa dapat dijelaskan berdasarkan indikator dari hasil yang diperoleh. Efektivitas kerja dosen pada Program Studi pendidikan Biologi hampir seluruh indikator dari variabel efektivitas kerja termasuk dalam kategori baik dan sangat baik, terkecuali ada 3 dosen yang mendapat penilaian hanya berada pada rentang 2,0-2,9 (pada kategori kurang baik dan tidak baik).

Menurut analisis deskriptif, maka dengan ini efektivitas kerja dosen Program Studi Pendidikan Biologi di bidang pendidikan dan pengajaran sudah baik, dan tetap perlu ditingkatkan. Keefektifan kinerja seorang dosen dalam melaksanakan tugasnya di bidang pendidikan dan pengajaran di dalam penelitian ini diukur dari waktu penyelesaian kewajiban mengajarnya, penguasaan materi, ketepatan penggunaan sarana pengajar, dan hasil pengajaran. Sebab tidak hanya kemampuan akademisnya yang akan mampu mencetak lulusan sarjana yang dibutuhkan, tetapi kehandalannya dalam mempergunakan alat bantu ajar serta ciri khasnya dalam menyampaikan ilmu kepada mahasiswa tentunya mempengaruhi tercapainya tujuan pelaksanaan tugas di bidang pendidikan dan pengajaran itu. Berikut uraian yang lebih jelas mengenai efektivitas kerja dosen berdasarkan hasil penelitian : (1). Waktu penyelesaian kewajiban mengajar oleh dosen menyangkut ketepatan mengajar, yang terlihat dari perkuliahan yang diberikan dosen yang sudah memenuhi jumlah pertemuan kelas tiap mata kuliah yang dibina, sebagian sangat mampu mempergunakan waktu perkuliahan secara maksimal pada tiap mata kuliah yang diajarkan dan sebagian lagi merasa cukup mampu saja. Secara keseluruhan dosen masuk tepat waktu sesuai dengan jadwal yang ditentukan, atau sesuai waktu kesepakatan bersama pada saat kontrak perkuliahan sebelumnya; (2). Penguasaan materi oleh dosen program studi pendidikan biologi dalam melaksanakan tugas pengajaran, yang terlihat dari tingkat pencapaian tujuan mengajar, serta adanya kemampuan dalam melaksanakan tugas pengajaran tanpa fasilitas pengajaran yang memadai. Selain itu adanya kemampuan yang sangat baik dari dosen untuk memaksimalkan daya pikir saat mengajar, pola pikir yang terbuka terhadap mahasiswa pada saat mengajar, serta penerapan komunikasi dua arah yang sangat baik oleh dosen pada saat mengajar. Dalam hal ini ditekankan pada bagaimana dosen tersebut bisa mentransfer ilmunya untuk mencapai tujuan pengajaran setiap pertemuannya. Hal ini akan berdampak pada mahasiswa yang nantinya tercermin dari hasil belajar mereka; (3). Ketepatan penggunaan sarana mengajar (penggunaan media dan metode mengajar). Ketepatan penggunaan sarana mengajar oleh dosen menyangkut penggunaan media pengajaran dan metode mengajar. Hal ini tercermin dari tingkat kehandalan yang cukup baik dalam mempergunakan OHP bahkan Laptop dan LCD sebagai peralatan mengajar sudah mampu dioperasikan dosen dengan baik, selain itu dalam proses praktikum penggunaan alat dan bahan yag seyogianya dapat dioperasikan dan langsung didemonstrasikan oleh dosen yang bersangkutanpun sudah baik, walaupun tidak dapat dipungkiri ketersediaan alat dan bahan praktikum masa terbatas. 
Selanjutnya metode mengajar dosen bervariasi berdasarkan materi yang diajarkan, dosen prodi pendidikan biologi banyak menerapkan metode diskusi bersama serta metode inkuiri(menggali, menemukan informasi sendiri berdasarkan materi perkuliahan melalui proses belajar setiap pertemuan); (4). Evaluasi hasil pengajaran, hasil pengajaran yang dilakukan oleh dosen Program Studi pendidikan biologi tercermin dari cara penilaian yang obyektif yang sangat baik dari dosen dalam memberikan penilaian hasil pembelajaran mahasiswa, walaupun nilai yang diberikan bervariasi berdasarkan hasil yang mahasiswa peroleh saat ujian, namun dosen-dosen memberikan remedial maupun pengayaan yang semuanya sudah terlaksana dengan baik. Penilaian ini sangat efektif dilakukan karena mahasiswapun menyadari kemampuan yang mereka miliki, sehingga mereka terpacu untuk mau berusaha memperbaiki semua aspek dalam evaluasi diri mereka,

Hasil analisis yang dilakukan ini menggambarkan secara umum efektifitas kinerja dosen pada program studi pendidikan biologi sudah baik. Dari empat (4) komponen penelitian yang telah dianalisis, mencerminkan bahwa secara umum mulai dari kesiapan dosen hingga evakuasipengajaran yang dilakukan, berimplikasi pada keluaran program studi. Hal inipun nyata dari alumni-alumni yang sudah dihasilkan. Banyak alumni yang telah bekerja dan menorehkan prestasi gemilang pada instansi kerja mereka, Sebagaimana Sedarmayanti (2004) mengemukakan bahwa efektivitas adalah setiap proses kegiatan dan kelembagaan yang diarahkan untuk menghasilkan sesuatu yang benar-benar sesuai dengan kebutuhan melalui pemanfaatan yang sebaik-baiknya dari berbagai sumber-sumber yang tersedia. Maka dalam konteks efektivitas kerja dosen dalam bidang pendidikan dan pengajaran, "sesuatu" yang ingin dihasilkan disini adalah para lulusan sarjana yang mencapai kualitas tertentu sebagaimana yang direncanakan oleh penyelenggara pendidikan. Para lulusan sarjana tersebut akan dapat diwujudkan melalui pemanfaatan berbagai sumber-sumber yang tersedia dengan sebaikbaiknya. Adapun sumber utama daripada upaya pemanfaatan tersebut adalah SDM pencetak lulusan sarjana, yaitu dosen. Semakin efektif dosen selaku tenaga pengajar bagi mahasiswa, maka diharapkan mahasiswa mampu menyerap ilmu yang disampaikan dosen, yang menjadi bekal mereka dalam menyandang gelar kesarjanaannya.

Berdasarkan hasil penelitian kinerja dosen secara keseluruhan dari empat aspek penelitian berada pada kategori baik (rentang skor 3,4-4,2). Hal ini tidak terlepas dari kompetensi yang di miliki oleh dosen pada program studi pendidikan biologi. Salah satunya adalah kemampuan mempersiapkan perkuliahan, kemampuan perencanaan dosen dalam melaksanakan pembelajaran (kesiapan dosen dalam memberikan kuliah ataupun praktikum) dosen selalu merencanakan metode serta materi apa yang akan diajarkan kepada mahasiswanya. Hal tersebut sesuai dengan pendapat Hamzah (2007) dalam Abdullah (2013) yang menyatakan tugas dosen/guru sebagai perancang pembelajaran meliputi: menyiapkan materi yang relevan dengan tujuan, waktu, fasilitas, perkembangan ilmu, kebutuhan dan kemampuan peserta didik, komprehensif, sistematis, dan fungsional efektif. Selain itu dosen juga harus mampu merancang metode yang disesuaikan dengan situasi dan kondisi peserta didik.

Selain hal tersebut, sarana dan prasarana sangat menunjang keefektifan dosen dalam melaksanakan tugasnya. Dalam pengajaran biologi tidak terlepas dari sarana penunjang, karena mata kuliah biologi sebagian besar melakukan kegiatan praktikum. Jika sarana penunjang memadai, baik ruang kelas, Ruang laboratorium, alat dan media ajar, serta bahan-bahan praktikum tersedia dengan baik, maka suasana dan kondisi belajar yang optimal terwujud sehingga tujuan yang diharapkan dapat dicapai secara optimal. hasil penelitian menunjukkan pada program studi pendidikan biologi walaupun masih ada beberapa alat dan bahan praktikum yang belum tersedia, namun praktikum tetap berjalan dengan kreatifitas dan inovasi yang dilakukan oleh dosen yang bersangkutan untuk melakukan pratikum secara sederhana. Hal ini senada dengan hasil penelitian yang dilakukan oleh Sudiro (2015), yang menyatakan bahwa sarana berpengaruh terhadap kinerja dosen. Adanya sarana dapat mendukung proses pembelajaran yang dilakukan oleh dosen baik di dalam kelas maupun di laboratorium. 
Tidak dapat dipungkiri bahwa adapula dosen yang masih kurang mampu dalam kinerjanya. Ada beberapa dosen memiliki kinerja yang masih bernilai rendah atau belum optimal, hal ini berdasarkan hasil yang diperoleh yaitu dengan rerata 2,0-2,9 berada pada kategori kurang baik dan tidak baik, Hal ini sangat mempengaruhi kinerja dosen tersebut. Hasil penelitian membuktikan bahwa ada beberapa dosen yang tidak dapat melaksanakan kewajiban dengan baik, tercermin bahwa dosen yang bersangkutan belum mampu memaksimalkan waktu pengajar, terkadang masuk tidak tepat waktu dan keluar kelaspun terlalu cepat, sehingga tujuan pembelajaran tidak tercapai secara optimal. Selain itu transfer materi yang tidak menggunakan metode yang tepat mengakibatkan semakin rendahnya pemahaman mahasiswa terhadap mata kuliah yang diampuhnya. Hal ini terjadi karen kurangnya motivasi dari dosen tersebut untuk melaksanakan tugasnya serta kurangnya rasa tanggungjawab terhadap kewajibannya sebagai seorang dosen. Senada dengan Rohayati (2014) mengemukakan bahwa rendanya kinerja dosen dapat disebabkan oleh beberapa factor seperti komitment yang rendah, motivasi dan kemampuan yang rendah, iklim perguruan tinggi yang kurang kondusif, serta balas jasa terhadap dosen yang kurang seimbang.

Selain hal tersebut di atas, rendahnya kinerja dosen ditentukan oleh kerja sama tim yang kurang, sehingga perencanaan kegiatan mengajarpun tidak optimal dilakukan yang tentunya hal ini bisa membuat jam/waktu mengajar menjadi tidak efektif. Hal ini pula senada dengan penelitian oleh Maharsi (2011) mengatakan bahwa ada beberapa factor yang diperkirakan menghambat rendahnya / kurangnya kinerja dosen antara lain, kerja sama tim yang kurang efektif, sehingga penggunaan waktu mengajar tidak maksimal, kurangnya teknologi ataupun peralatan kerja yang tidak tepat, sehingga penyampaian atau transfer materi tidak sampai dengan baik kepada mahasiswa, perencanaan kegiatan yang tidak sesuai kebutuhan, dosen kurang/tidak termotivasi. Maka hendaknya hal-hal tersebut perlu dibenahi dalam rangka pencapaian tujuan yang telah direncanakan sebelumnya oleh Program Studi pendidikan biologi sebagai salah satu bagian terpenting dari organisasi FKIP mencapai tujuan pendidikan mencetak para guru-guru yang andal dan berkompeten.

Banyak hal yang dapat mempengaruhi keektifitasan kinerja dosen. Temuan penelitian menunjukkan bahwa banyak factor yang mempengaruhi kinerja dosen salah satunya adalah kompetensi professional (kompetensi pedagogic). Oleh karena itu, untuk mengoptimalkan kinerja dosen harus diupayakan pula bagaimana meningkatkan kompetensi professional sehingga dosen dapat menjalankan tugasnya lebih baik lagi. Hal ini menuntut bagi setiap dosen wajib mengembangkan ataupun menambah ilmunya ke jenjang yang lebih tinggi. Namun dalam hal ini prodi pendidikan biologi telah melakukannya, dengan mengirimkan beberapa dosennya untuk melakukan studi lanjut. Jadi secara keseluruhan keefektifitasan kinerja dosen pada program studi pendidikan biologi sudah baik.

Temuan penelitian ini, diperkuat dengan pernyataan yang dikemukakan oleh Trisnaningsih (2011) yang menyimpulkan bahwa factor-faktor yang dapat mempengaruhi kinerja dosen meliputi komitmen, pengetahuan, ketrampilan, dan motivasi ". Dengan demikian kompetensi professional dosen dalam hal ini baik melalui pendidikan formal maupun informal untuk memperoleh pengetahuan dan ketrampilan sangat perlu ditingkatkan untuk kepentingan peningkatan kinerja dosen. Sebagai implikasinya, maka dari pihak dosen sendiri harus memiliki kemauan untuk terus meningkatkan pengetahuan dan ketrampilan serta kompetensinya sehingga dapat menunjang pelaksanaan tugasnya sebagai pendidik.

Jika seorang dosen benar-benar melaksanakan tugas dan fungsinya dengan baik dan benar, maka hasilnyapun akan optimal. Proses pengajaran akan berjalan dengan baik, peerapan metode yang bervariasi, penggunaan sarana dan prasarana yang memadai serta evaluasi yang benar. Pada program studi pendidikan biolgi walaupun belum secara keseluruhan dosen-dosen mampu melakukan tugasnya secara optimal, namun secara umum kinerja dosen sudah baik didukung oleh hasil penelitian yang ada. 


\section{KESIMPULAN}

Berdasarkan hasil dan pembahasan, maka dapat disimpulkan bahwa kinerja dosen pada program studi pendidikan biologi berada pada kategori baik.

\section{DAFTAR PUSTAKA}

Abdullah Ali. 2013. Studi Deskriptif Kinerja Dosen Dalam Proses Pembelajaran di Universitas Muhammadiyah Surakarta. University Research Colloquium.

Maharsih. 2011. Upaya penigkatan kinerja dosen di Indonesia yang masih terkendala minimnya kompensasi. Jurnal pengembangan humaniora, volume II. Nomor 2. Agustus 2011.

Rohayati. 2014. Pengaruh kepuasan kerja terhadap Citizenship Behavior : studi pada yayasan masyarakat madani Indonesia. Jurnal studi management research volume XI, No.1 2014.

Sedarmayanti. 2004 . Manajemen Sumber Daya Manusia, Reformasi Birokrasi Manajemen Pegawai Negeri Sipil. Bandung : Rafika Aditama.

Sudiro. 2015. Pengaruh sarana, proses pembelajaran, dan persepsi kinerja dosen terhadap kepuasan mahasiswa pada politeknik indonusa surakarta. Jurnal Sainstech Politeknik Indonusa Surakarta ISSN : 2355-5009 Vol. 1 Nomor 4 Desember Tahun 1

Trisnaningsih. 2011. Factor-faktor yag mempengaruhi kinerja dosen akuntansi. Jurnal akuntansi auditing vol.8.november 2011.

Undang-Undang Guru dan Dosen No.14 Tahun 2005

Widoyoko, S.E.P. 2012. Teknik Penyusunan Instrumen Penelitian. Yogyakarta: Pustaka Pelajar. 